\title{
Ea
}

\section{BUFEN MALS AIRES A L'ENSENYAMENT PÚBLIC. PER QUÈ?}

Els governs de torn que ens hem atorgat democràticament al país i a l'Estat demostren, en aquests moments, amb actes concrets, continuats i interconnectats, que no creuen en l'ensenyament públic, salvaguarda d'una educació igualitària per a tots els alumnes de totes les classes socials. Sovint escenifiquen divergències educatives que, analitzades en el fons del fons, són clarament convergents, amb unes lleugeres discrepàncies de matís que els fa presentar diferents a bona part de l'opinió pública en l'acció del dia a dia, però sensiblement idèntics en l'acció de base, que és veritablement la que compta.

Hi ha massa problemes a l'ensenyament que caldria eradicar. A l'ensenyament públic de base li surten núvies i amistançades pertot, en format d'escoles classistes, buscant atrapar els diners públics per completar les quotes emmascarades que cobren a l'èlit social que formen, fent que el pressupost global s'aprimi tant que faci rebrotar diferències brutals d'escoles dotades enfront de les infradotades. La filosofia de l'ensenyament no defensa una igualtat d'oportunitats perquè no hi ha oportunitats iguals per a la gent del país. El sistema educatiu té moltes, massa, llacunes, una petita mostra de les quals són les que hem apuntat. La Reforma, com a premissa bàsica, pretenia reformar, igualar. I ens quedem aquí. Segurament, li haurien calgut molts i molts retocs en el curs de la seva trajectòria. Normal. La Reforma l'aplica, però, un partit que no volia la Reforma. Conseqüentment, la Reforma queda aigualida i es converteix en una contrareforma, on aspectes que semblaven molt clars són qüestionats, matisats, reformulats, redefinits, amb un llenguatge subliminal que pot confondre al començament, però que parla clar quan es desenvolupa en el currículum. Si no, a què ve aquesta Ley de calidad? A Infantil i Primària l'envestida, si s'aprova, farà mal.

A Infantil es desestructura el primer cicle, el de zero a tres anys, i això comporta que quedi desdibuixat. Amb la pretensió encoberta que tingui un caràcter educatiu i assistencial, la rebaixa de perspectiva educativa esfereeix, retallant els avenços psicopedagògics dels darrers temps. A Primària es vol donar més força a les àrees instrumentals, trencant els cicles, marginant l'àrea de música i convertint en una "maria" una plàstica ja per si mateixa prou davaluada i castigada. Senzillament, no entenem per què haurem de formar mestres especialistes per impartir classes del no-res.

L'escola, poden dir molts, ha millorat qualitativament des del 1970, i convenim que és cert. Sens dubte. La millora, feta extensiva en qualitat i quantitat, ha estat inqüestionable, però el perill d'un retrocés gairebé sempre ha estat present. Ara, més que mai, veiem que aquest existeix en format virtual $\mathrm{i}$ efectiu, i per això ho manifestem. La declaració educativa de Bolònia, en format de recomanació del que ha de ser l'educació, sembla que no ha passat els Pirineus. Retornarem, potser, als vells fantasmes del passat? Ens caldrà diàleg i compromís. 